\title{
Reproductive System Findings Completion
}

\section{Status}

National Cancer Institute

\section{Source}

National Cancer Institute. Reproductive System Findings Completion Status. NCI

Thesaurus. Code C117649.

A term used to describe the state or condition of the completeness of the reproductive system findings data. 